\title{
Hydrochemistry of the Mocorito river coastal aquifer, Sinaloa, Mexico: water quality assessment for human consumption and agriculture suitability
}

\author{
Hidroquímica del acuifero costero del Río Mocorito, Sinaloa, México: evaluación de la calidad del agua para consumo humano y \\ agricultura
}

\author{
José R. Rivera-Hernández' ${ }^{1}$ Carlos Green-Ruiz², Lawren Pelling-Salazar and Alejandra Trejo-Alduenda ${ }^{1}$ \\ 'Posgrado en Ciencias del Mar y Limnología, Universidad Nacional Autónoma de México. Av. Joel Montes Camarena s/n, Col. Playa Sur, Mazatlán, Sin., 82040. México \\ ${ }^{2}$ Unidad Académica Mazatlán, Instituto de Ciencias del Mar y Limnología, Universidad Nacional Autónoma de México. Av. Joel Montes Camarena s/n, \\ Col. Playa Sur, Mazatlán, Sin., 82040. México \\ e-mail: cgreen@ola.icmyl.unam.mx
}

Recibido: 13 de julio de 2015.

Aceptado: 15 de febrero de 2017

Rivera-Hernández J. R., C. Green-Ruiz, L. Pelling-Salazar and A. Trejo-Alduenda. 2017. Hydrochemistry of the Mocorito river coastal aquifer, Sinaloa, Mexico: water quality assessment for human consumption and agriculture suitability. Hidrobiológica 27 (1): 103-113. D0l: 10.24275/uam/izt/dcbs/hidro/2017v27n1/Green

\begin{abstract}
Background. Groundwater is a vital source of water for domestic and agricultural activities and the water of the Mocorito River Coastal Aquifer (MORCA), located in the agricultural valley of Culiacan, Sinaloa, Mexico, is not an exception. Goals. To assess MORCA's groundwater quality for drinking and irrigation purposes and the geochemical processes affecting its composition. Methods. Twenty-two well samples were collected during the dry and rainy seasons. Physical and chemical parameters, major ions, drinking quality (WQI and PHASECH water quality index), and irrigation suitability Richards (1954) and Wilcox diagrams) were studied. Results. Total Dissolved Solid (TDS) ranged from 1688 - $8762 \mathrm{mg} \mathrm{L}^{-1}$ for the dry season and 89-10016 $\mathrm{mg} \mathrm{L}^{-1}$ for the rainy season. From inland to the coastal zone, MORCA's groundwater was considered hard and very hard, with non-dominant hydrochemical facies in the dry season and calcium, magnesium and sodium (cationic), and bicarbonate and chloride (anionic) types, in the rainy season. US Salinity Staff and Wilcox diagrams revealed that MORCA's groundwater is not suitable for use in irrigation. Further, the geochemical processes controlling the chemical composition of MORCA were evaporation and weathering. Conclusions. According to the TDS and water quality index (WQI and PHASECH) classifying just $4.5 \%$ and over $50 \%$ of the samples, respectively, MORCA water can be considered suitable for human consumption; only the groundwater from site EE-1, in the rainy season, was considered suitable for human consumption. US Salinity staff and Wilcox diagrams indicate that almost 50\% of MORCA's groundwater is not suitable for irrigation use. MORCA's groundwater composition is dominated by evaporation and weathering of minerals such as anorthite, illite, and kaolinite.
\end{abstract}

Key words: Geochemical processes, hydrochemical facies, major ions, Piper diagram.

\section{RESUMEN}

Antecedentes. El agua subterránea es una fuente vital de agua tanto para actividades domésticas como agrícolas; y el agua del acuífero costero del río Mocorito (MORCA), localizado dentro del valle agrícola de Culiacán, Sinaloa, México, no ha sido la excepción. Objetivos. Evaluar la calidad del agua subterránea del MORCA para propósitos de consumo humano e irrigación, así como conocer los procesos geoquímicos que gobiernan su composición. Métodos. Veintidós muestras de agua de pozo fueron colectadas en épocas de sequía y de lluvias. Parámetros fisicoquímicos, iones mayoritarios, calidad del agua para consumo humano e irrigación fueron estudiados. Resultados. Los valores de TDS variaron de 1688-8762 $\mathrm{mg} \mathrm{L}^{-1}$ para época de secas y 89-10016 $\mathrm{mg} \mathrm{L}^{-1}$ para lluvias. Desde tierra adentro hacia la zona costera, el agua subterránea del MORCA se consideró de dura a muy dura, observando que las facies hidroquimicas son principalmente de tipo no-dominante, en época de secas; mientras que en Iluvias son clasificadas como de tipo cálcio-magnesio-sódica (catiónico) y bicarbonato y cloruro (aniónico). Los diagramas US Salinity Staff y Wilcox revelaron que el agua subterránea del MORCA no es apta para usos en irrigación. Por otro lado, los procesos geoquímicos que controlan la composición química de MORCA fueron la evaporación y meteorización. Conclusiones. De acuerdo con la clasificación del contenido de TDS e índices de calidad del agua (WQI y PHASECH) solo el $4.5 \%$ y más del $50 \%$ de las muestras, respectivamente, pueden ser consideras apropiadas para el consumo humano. En el caso de aptitud agrícola, los diagramas US Salinity Staff and Wilcox, indicaron que casi 50\% del agua subterránea del MORCA no es apta para ese propósito. La composición del agua subterránea del MORCA es dominada por evaporación y meteorización de minerales como anortita, illita y caolinita.

Palabras clave: Diagrama de Piper, faces hidroquímicas, iones mayoritarios, procesos geoquímicos. 


\section{INTRODUCTION}

Groundwater is the major source of water supply around the world and is mainly employed for domestic, agricultural, and industrial activities. Groundwater chemistry determines its quality and therefore its proper use. It is influenced by natural factors such as climatic conditions, rain and surficial water percolation, recharge water quality, regional geology, sub-surficial geochemical processes, as well as discharges, leaching and organic matter addition from anthropogenic activities carried out over the aquifer, extraction, and irrigation practices (Brindha \& Elango, 2011; Davraz \& Özdemir, 2013).

In some places, groundwater is vital for human consumption and biota, thus continuous quality monitoring is crucial since irrigation with poor quality groundwater could threaten the health of all consumers and inhibit the growth and quality of crops. The hydrogeochemical study of groundwater is essential to understand the origin and evolution of its chemical composition and hence its quality. There is an extensive literature on groundwater quality assessment for human consumption and agricultural uses (Onwuka et al., 2013; Murkute, 2014; Dar et al., 2014; Krishna-Kumar et al., 2014), based on conventional techniques such as the Piper (1953) and Gibbs (1970) diagrams in order to identify hydrochemical facies and geochemical processes. There are also quality indices like WQI (Vasanthavigar et al., 2010; Krishna-Kumar et al., 2014) and PHASECH (Peinado-Guevara et al., 2011); Richards (1954) and Wilcox (1948) diagrams for assessment of agricultural suitability.
All of them take into account groundwater chemical composition (e.g., major ions, total dissolved solids, $\mathrm{pH}$ and conductivity). There are no studies on groundwater quality assessment in the MORCA area. However, Peinado-Guevara et al. (2011) studied the Sinaloa River coastal aquifer (SIRCA), the northern neighbor basin (between $25^{\circ} 16^{\prime} 38^{\prime \prime}$ and $25^{\circ} 41^{\prime} 13^{\prime \prime} \mathrm{N}$ and from $108^{\circ} 25^{\prime} 02^{\prime \prime}$ to $108^{\circ} 41^{\prime} 22^{\prime \prime} \mathrm{Wt}$ ), and concluded that the SIRCA is highly sensitive to salinization due to its coastal condition, with a latent threat of saltwater intrusion during droughts, as well as the occurrence of evaporitic rocks away from the coast line.

\section{MATERIALS AND METHODS}

Study area. The Mocorito River Coastal Aquifer (MORCA), with an area of $1180 \mathrm{~km}^{2}$, lies between $24^{\circ} 56^{\prime} 17^{\prime \prime} \mathrm{N}$ and $25^{\circ} 47^{\prime} 26^{\prime \prime} \mathrm{N}$, and $107^{\circ}$ $38^{\prime} 07^{\prime \prime}$ and $108^{\circ} 23^{\prime} 35^{\prime \prime}$ W (Fig. 1.), in the central portion of the state of Sinaloa, Mexico, adjacent to important cities. It is an unconfined aquifer with fluvial and alluvial sediments (Cretaceous to Tertiary) lying on a consolidated conglomerate of low permeability, which in turn overlies volcanogenic materials (acid igneous rocks with the presence of $\mathrm{Au}, \mathrm{Ag}$, $\mathrm{Cu}, \mathrm{Pb}$ and $\mathrm{Fe}$ ) (Anonymous, 1978). MORCA's recharge is approximately $208 \times 10^{6} \mathrm{~m}^{3} /$ year (Comisión Nacional del Agua, 2009a). The Mocorito River basin (180 km in length) has its origin in the town of Terrero (Cerro San Pedro-Sierra Madre Occidental), at $1950 \mathrm{~m} \mathrm{AMSL}$, and its river mouth is on the Santa María La Reforma coastal lagoon, Playa Colorada bay (INEGI, 1995).

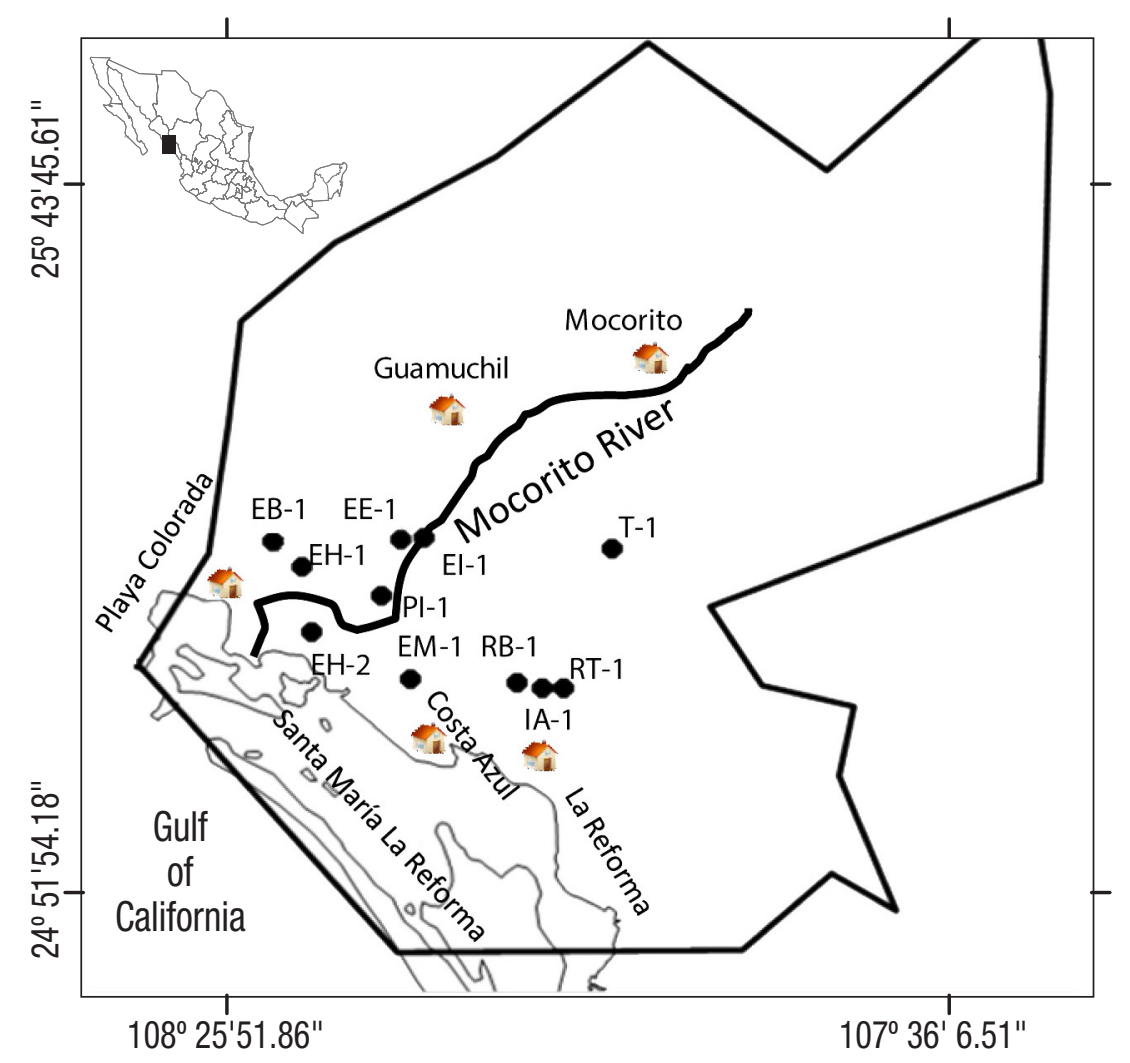

Figure 1. Location of the Mocorito River coastal aquifer area (Sinaloa, Mexico) and sampling stations. 
The Culiacan Valley, where the MORCA is located, is the most important agricultural region in Sinaloa, with intensive agriculture activity (193,481 ha irrigated and 184,547 ha rain-fed) (Páez-Osuna et al., 2007), growing vegetables such as corn, tomatoes, chili, and sorghum. Thus the main use for MORCA's groundwater, mainly in the dry season, is for irrigation; however, during drastic climatic events like drought or hurricanes, some communities employ groundwater for their drinking water consumption.

According to the Köppen Climate Classification System, modified by García (1964), the MORCA area has a warm, very dry climate, with an average annual temperature of $22{ }^{\circ} \mathrm{C}$, and the rainy season occurs during summer (BW ( $\left.\left.\mathrm{h}^{\prime}\right) \mathrm{W}\left(\mathrm{e}^{\prime}\right)\right)$. The precipitation on the MORCA region was $846.7 \mathrm{~mm}$ in 2013; however, significant variations were observed between both dry ( 0.1 and $0.2 \mathrm{~mm}$ in March and April, respectively) and rainy (169.4, 197.2 and $298.6 \mathrm{~mm}$ in July, August, and September) seasons (CONAGUA, 2014).

The main objective of this study was to evaluate the groundwater quality for both human consumption and agricultural suitability of the Mocorito River Coastal Aquifer in two different climatic seasons, using hydro-geochemical tools. Groundwater in this region is employed for irrigation and drinking water.

Sampling. Using a Bailer sampler, groundwater samples were collected from a network of 22 coastal wells (on average, the water table was $7 \mathrm{~m}$ below ground level) in two different climatic seasons, i.e., April (dry) and July (rainy) 2013 (Fig. 1). All the groundwater samples were collected $1 \mathrm{~m}$ below the water table. Sampling wells were selected based on the National Water Commission (CONAGUA, for its acronym in Spanish) (CONAGUA) well network. In addition, depending on their accessibility, we also took samples on private property, in houses and agriculture fields. Samples were collected in $60 \mathrm{~mL}$ high-density polyethylene (HDPE) bottles for chemical elements (cations and anions) and stored at $4{ }^{\circ} \mathrm{C}$ until they could be chemically analyzed in the laboratory. Auxiliary environmental parameters $(\mathrm{pH}$, temperature, total dissolved solids (TDS), and Electrical conductivity (CE)) were measured in situ with previously calibrated potentiometers (HANNA models HI98127 and HI98130). Cation and anion concentrations were volumetrically $\left(\mathrm{Ca}^{2+}\right.$, $\left.\mathrm{Cl}^{-}, \mathrm{CO}_{3}{ }^{2-}, \mathrm{HCO}_{3}{ }^{-}\right)$, gravimetrically $\left(\mathrm{Mg}^{2+}, \mathrm{SO}_{4}{ }^{2-}\right)$ with drying of residue, and flamometrically $\left(\mathrm{Na}^{+} \mathrm{y} \mathrm{K}^{+}\right)$defined in the Water, Soil and Plant Analysis Laboratory of the Irrigation District 010 Culiacán-Humaya of CONAGUA, a federal agency. Procedures were based on the soil and water analysis manual from the Agriculture and Hydric Resources Ministry of Mexico (Secretaría de Agricultura y Recursos Hidráulicos, 1974). Quality assessment for cations and anions concentrations was carried out according to the following ionic balance error expression proposed by Cabrera-Sansores et al. (2002):

$\%$ Error $=(\Sigma$ cationes $-\Sigma$ aniones $) /\left(\sum\right.$ cationes $+\sum$ aniones $) * 100$

where $\%$ Error must be less than $10 \%$.

Total dissolved solids (TDS) content, soluble sodium percentage $(\%$ $\mathrm{Na}^{+}$), the sodium-adsorption-ratio (SAR), and total hardness (TH) were determined following the equations:

$$
\begin{aligned}
& \text { TDS }=\mathrm{EC} / 1.65 \text { in mhos } / \mathrm{cm} \\
& \text { TH }=2.497 \mathrm{Ca}^{2+}+4.115 \mathrm{Mg}^{2+} \\
& \% \mathrm{Na}^{+}=\mathrm{Na}^{+}+\mathrm{K}^{+} \times 100 / \mathrm{Ca}^{2+}+\mathrm{Mg}^{2+}+\mathrm{Na}^{+}+\mathrm{K}^{+}
\end{aligned}
$$

$$
\mathrm{SAR}=\mathrm{Na}^{+} / \sqrt{ }\left(\mathrm{Ca}^{2+}+\mathrm{Mg}^{2+}\right) / 2
$$

where all ionic concentrations are expressed in meq/L for ecs. (3), (4), and (5).

Equation (2) was described by Peinado-Guevara et al. (2011) from a database compiled during more than 20 years, which takes into account the electrical conductivity (EC) of each sample. Equations 3, 4, and 5 were used by Vasanthavigar et al. (2010).

Once all the values were obtained, hydrochemical facies and the geochemical processes involved were identified using the Piper (1953) and Gibbs (1970) diagrams. Quality of drinking water was evaluated using two indices, WQI (Vasanthavigar et al., 2010; Krishna-kumar et al., 2014) and PHASECH (Peinado-Guevara et al., 2011). Agriculture suitability was evaluated with the diagrams proposed by Richards (1954) and Wilcox (1948).

\section{RESULTS}

Results of laboratory and in situ measurements, data of environmental and hydrochemical parameters, TDS, and secondary parameters (\% $\mathrm{Na}^{+}$, SAR and $\mathrm{TH}$ ) are reported in Table 1. Overall, $\mathrm{pH}$ values were within an acceptable range that is suitable for human consumption (Secretaría de Salud, 2000), i.e., 6.8 and 8.4, averaging 7.6, during the dry season and 7.3 to 8.5 , averaging 7.9 during the rainy season. The temperature of MORCA's groundwater averaged 26.6 and $28.3^{\circ} \mathrm{C}$ in dry and rainy seasons, respectively. Likewise, EC high values were measured in both climatic seasons; they oscillated between 1,023 and $5,310 \mu \mathrm{S} \mathrm{cm}^{-1}$, averaging $2,223 \mu \mathrm{S} \mathrm{cm}^{-1}$ in the dry season; and from 54 to $6,070 \mu \mathrm{S}$ $\mathrm{cm}^{-1}$, with an average of $2,343 \mu \mathrm{S} \mathrm{cm}{ }^{-1}$ in the rainy season. TDS values (Table 1) during the dry season $\left(1,688-8,761.5 \mathrm{mg} \mathrm{L}^{-1}\right)$ were higher than those in the rainy season $\left(89-10,015.5 \mathrm{mg} \mathrm{L}^{-1}\right)$. Total hardness (TH) values were found between 180 to $2,001 \mathrm{mg} \mathrm{L}^{-1}$ in the dry season and 25 to $1,750 \mathrm{mg} \mathrm{L}^{-1}$ in the rainy season.

The concentrations of $\mathrm{Ca}^{2+}$ ranged between 2.3-20.8 meq $\mathrm{L}^{-1}$ in the dry season and 0.3-7.3 meq $\mathrm{L}^{-1}$ in the rainy season. $\mathrm{Mg}^{2+}$ fell below 19.2 meq L $^{-1}$, with a minimum of 0.5 meq L $^{-1}$ in the dry season and 31.9 and 0.2 meq $\mathrm{L}^{-1}$ in rainy season. $\mathrm{Na}^{+}$varied from 2.7 to 14.7 meq $\mathrm{L}^{-1}$ in the dry season and from not detectable to 34.4 meq $\mathrm{L}^{-1}$ in the rainy season. Anions had a lower content, except the case of $\mathrm{Cl}^{-}$, which had a minimum of $0.8 \mathrm{meq} \mathrm{L}^{-1}$, with a maximum of $34 \mathrm{meq} \mathrm{L}^{-1}$ in the dry season, and a minimum of 0.1 meq $\mathrm{L}^{-1}$ and a maximum of 35 meq $\mathrm{L}^{-1}$ in the rainy season.

\section{DISCUSSION}

Groundwater chemistry. A wider variation of EC was found in the rainy season, which can be related with dilution and/or differential rock-water interactions during water infiltration from the surface to the aquifer. According to Sánchez-Pérez and Trémolières (2003), Choi et al. (2005), and Murkute (2014), groundwater with high EC and large variations of this parameter are attributed to an ion exchange and solubilization processes within the aquifers (geochemical processes through water-rock interaction), as well as anthropogenic activities in aquifers. Peinado et al. (2011) have registered the occurrence of salt domes or lenses in the region. This kind of geological bodies can also produce the high EC values, especially in sites far from the coastline. In accordance with the irrigation water EC classification proposed by Richards (1954), 
Table 1. Environmental and physicochemical parameters of groundwater samples from the Mocorito River coastal aquifer (MORCA), Sinaloa, Mexico. Units: Major ions (meq/L), T = temperature $\left({ }^{\circ} \mathrm{C}\right), \mathrm{S}=$ salinity $(\%)$, EC $(\mu \mathrm{S} / \mathrm{cm}), \mathrm{TDS}(\mathrm{mg} / \mathrm{L}), \mathrm{TH}(\mathrm{mg} / \mathrm{L})$, SAR (Sodium-Adsorption-Ratio, no units), and $\% \mathrm{Na}(\%)$.

\begin{tabular}{|c|c|c|c|c|c|c|c|c|c|c|c|c|c|c|c|c|}
\hline ID & $\mathrm{pH}$ & $\mathrm{T}$ & $S$ & EC & TDS & TH & $\mathrm{Na}^{+}$ & $\mathrm{Ca}^{2+}$ & $\mathrm{Mg}^{2+}$ & $\mathrm{Cl}-$ & $\mathrm{SO}_{4}^{2-}$ & $\mathrm{HCO}_{3}^{-}$ & $\mathrm{CO}_{3}^{2-}$ & SAR & $\% \mathrm{Na}$ & \%Error \\
\hline \multicolumn{17}{|c|}{ Dry season } \\
\hline EH-1 & 8.3 & 27.7 & 1 & 1104 & 1821.6 & 200.1 & 7.04 & 2.3 & 1.7 & 2.4 & 4.2 & 3.6 & 0.8 & 5 & 63.8 & 0 \\
\hline EH-2 & 7 & 23.8 & 2 & 2460 & 4059 & 700.3 & 10.6 & 6.7 & 7.3 & 13.8 & 5.6 & 4.8 & 0.4 & 4 & 43.1 & 0 \\
\hline EB-1 & 8.4 & 24.3 & 1 & 2250 & 3712.5 & 390.2 & 14.7 & 4 & 3.8 & 12.8 & 5.5 & 3.8 & 0.4 & 7.4 & 65.3 & 0 \\
\hline Pl-1 & 7.5 & 27.4 & 1 & 1023 & 1688 & 290.1 & 4.4 & 3.1 & 2.7 & 3.8 & 1.6 & 4 & 0.8 & 2.6 & 43.3 & 0 \\
\hline EE-1 & 6.9 & 26.6 & 0 & 1132 & 1867.8 & 430.2 & 2.7 & 3.3 & 5.3 & 2.6 & 3.3 & 4.6 & 0.8 & 1.3 & 24 & 0 \\
\hline $\mathrm{El}-1$ & 7.6 & 27.6 & 5 & 5310 & 8761.5 & 2000.9 & 13.1 & 20.8 & 19.2 & 34 & 14.1 & 5 & 0 & 2.9 & 24.7 & 0 \\
\hline EM-1 & 8.4 & 24.8 & 2 & 1657 & 2734.1 & 250.2 & 11.6 & 4.2 & 0.8 & 4.4 & 3 & 7.2 & 2 & 7.3 & 69.8 & 0 \\
\hline $\mid A-1$ & 6.8 & 29.6 & 0 & 1476 & 2435.4 & 450.1 & 5.8 & 2.3 & 6.7 & 7.2 & 2.6 & 4.6 & 0.4 & 2.7 & 39 & 0 \\
\hline RB-1 & 7.6 & 28.4 & 0 & 1042 & 1719.3 & 180.1 & 6.8 & 3.1 & 0.5 & 3 & 3.8 & 2.8 & 0.8 & 5.1 & 65.5 & 0 \\
\hline RT-1 & 8 & 26.2 & 2 & 3210 & 5296.5 & 980.4 & 12.5 & 7.3 & 12.3 & 12.6 & 13.7 & 5 & 0.8 & 4 & 38.9 & 0 \\
\hline $\mathrm{T}-1$ & 7.4 & 26.1 & 5 & 3790 & 6253.5 & 1520.7 & 7.5 & 15 & 15.4 & 20.6 & 13.5 & 3.4 & 0.4 & 1.9 & 19.8 & 0 \\
\hline \multicolumn{17}{|c|}{ Rainy season } \\
\hline EH-1 & 8.5 & 27 & 1 & 1084 & 1788.6 & 170.1 & 7.4 & 2.1 & 1.3 & 3 & 2.4 & 3.8 & 2.6 & 5.7 & 68.6 & 0 \\
\hline EH-2 & 7.3 & 27 & 0 & 2030 & 3349.5 & 520.2 & 9.9 & 3.1 & 7.3 & 10 & 5.1 & 4.8 & 0.4 & 4.3 & 48.8 & 0 \\
\hline EB-1 & 7.5 & 27 & 1 & 731 & 1206.2 & 150.1 & 4.3 & 1 & 2 & 2.8 & 1.9 & 2.2 & 0.4 & 3.5 & 59 & 0 \\
\hline Pl-1 & 8.3 & 28 & 0 & 1112 & 1834.8 & 300.1 & 5.1 & 2.1 & 3.9 & 3.8 & 2.3 & 3 & 2 & 3 & 46 & 0 \\
\hline EE-1 & 7.8 & 27 & 0 & 54.2 & 89.4 & 25 & 0.0 & 0.3 & 0.2 & 0.1 & 0 & 0.2 & 0.2 & 0.1 & 7.8 & 0 \\
\hline El-1 & 7.7 & 34 & 4 & 6070 & 10015.5 & 1750.4 & 25.7 & 3.1 & 31.9 & 35 & 22.7 & 1 & 2 & 6.1 & 42.3 & 0 \\
\hline EM-1 & 7.8 & 27 & 1 & 1576 & 2600.4 & 140.1 & 13 & 1.3 & 1.6 & 4 & 2 & 5.8 & 4 & 11 & 82.2 & 0 \\
\hline $\mid A-1$ & 8.5 & 33 & 1 & 1715 & 2829.8 & 450.1 & 8.2 & 2.3 & 6.7 & 8.8 & 2.2 & 4.2 & 2 & 3.8 & 47.5 & 0 \\
\hline RB-1 & 8.2 & 27 & 2 & 4140 & 6831 & 350.7 & 34.4 & 5.2 & 1.8 & 15 & 20.4 & 4 & 2 & 18.4 & 83.1 & 0 \\
\hline RT-1 & 8.1 & 27.5 & 3 & 3500 & 5775 & 1000.4 & 15 & 7.3 & 12.7 & 13.2 & 15.8 & 2.8 & 3.2 & 4.7 & 42.9 & 0 \\
\hline $\mathrm{T}-1$ & 7.7 & 27 & 2 & 3760 & 6204 & 1400.3 & 9.6 & 3.1 & 24.9 & 21 & 14.2 & 1.6 & 0.8 & 2.6 & 25.5 & 0 \\
\hline
\end{tabular}

on average, MORCA groundwater was classified as having very high salinity $\left(2,250-5,000 \mu \mathrm{S} \mathrm{cm}^{-1}\right)$.

Krishna-Kumar et al. (2014) suggested that waters with low TDS (373-895 $\mathrm{mg} \mathrm{L}^{-1}$ ) are influenced by rock-water interaction related to recharge, while waters with high TDS (959-4,669 $\mathrm{mg} \mathrm{L}^{-1}$ ) are influenced by anthropogenic sources. A classification of the type of groundwater based on TDS content (Heath, 1983) is shown in Table 2. Most of the samples from both seasons can be classified as slightly to moderately saline, except for one sample (El-1) took during the rainy season, which was classified as highly saline, and another (EE-1) from the same period that was classified as freshwater. According to the desirable maximal value of TDS suggested by the World Health Organization (WHO 2006; $500 \mathrm{mg} \mathrm{L}^{-1}$ ) and NOM-127-SSAl-1994 (Secretaria de Salud, 2000; $1,000 \mathrm{mg} \mathrm{L}^{-1}$ ), only $4.5 \%$ of the samples (site EE-1) during both seasons are considered suitable for human consumption.

Following Sawyer \& McCarty's classification (1967), all samples collected in the dry season are hard to very hard, while of those collected in the rainy season, $9 \%$ are soft, $9 \%$ are moderately hard, $18 \%$ are hard, and $64 \%$ are very hard (Table 3). Significant differences were not found for any of the aforementioned parameters in either climatic season. The World Health Organization (WHO 2006) and NOM-127-
SSAl-1994 (Secretaria de Salud, 2000) indicate that the maximal value of TH tolerated by human beings is $500 \mathrm{mg} \mathrm{L}^{-1}$. In this regard, most of the MORCA samples showed a good degree of hardness $(<500 \mathrm{mg}$ $\mathrm{L}^{-1}$ ), except for the EH-2, El-1, RT-1, and T-1 sites (>500 $\left.\mathrm{mg} \mathrm{L}^{-1}\right)$ in both seasons.

On average, the ionic order observed was $\mathrm{Cl}^{-}>\mathrm{Na}^{+}>\mathrm{Mg}^{2+}>\mathrm{Ca}^{2+}$ $>\mathrm{SO}_{4}{ }^{2-}>\mathrm{HCO}_{3}^{-}>\mathrm{CO}_{3}{ }^{2-}$ and $\mathrm{Na}^{+}>\mathrm{Cl}^{-}>\mathrm{Mg}^{2+}>\mathrm{SO}_{4}{ }^{2-}>\mathrm{HCO}_{3}{ }^{-}>\mathrm{Ca}^{2+}$ $>\mathrm{CO}_{3}^{2-}$ for dry and rainy seasons, respectively. A special concern involved the low observed $\mathrm{SO}_{4}{ }^{2-}$ concentrations (Table 1) in all samples $(\max =22.7 \mathrm{mg} / \mathrm{L}$, in well El-1), which may indicate reduction processes occurring in the system that produce sulfide minerals precipitates. Unfortunately, tests for $\mathrm{NO}_{3}, \mathrm{NO}_{2}$, and oxidation-reduction potential, some trace elements, and microbiological composition, which might serve as proxies for specifying the oxidation-reduction condition of water, were not carried out.

Hydrochemical facies and geochemical processes involved. The triangular Piper's diagram is commonly used in water chemistry studies to show the percentage of ionic composition and to identify water types. The study area showed significant variations in the concentrations of cationic and anionic composition (Figure 2). $\mathrm{Na}^{+}$and $\mathrm{Mg}^{2+}$ dominated over $\mathrm{Ca}^{2+}$; while prevalence of $\mathrm{HCO}_{3}{ }^{-}$and $\mathrm{Cl}^{-}$was evident in the anionic 
Table 2. Mocorito River coastal aquifer groundwater classification based on TDS content (Classification suggested by Heath, 1983).

\begin{tabular}{|c|c|c|c|c|c|c|c|c|c|c|c|}
\hline & EH-1 & $\mathrm{EH}-2$ & EB-1 & $\mathrm{PI}-1$ & $\mathrm{EE}-1$ & $\mathrm{El}-1$ & EM-1 & $\mid A-1$ & RB-1 & RT-1 & $\mathrm{T}-1$ \\
\hline \multicolumn{12}{|l|}{ Dry season } \\
\hline TDS (mg L-1) & 1821.6 & 4059 & 3712.5 & 1688 & 1867.8 & 8761.5 & 2734.1 & 2435.4 & 1719.3 & 5296.5 & 6253.5 \\
\hline Classification & $\mathbf{\square}$ & $\Delta$ & $\Delta$ & $\mathbf{\square}$ & $\Delta$ & $\Delta$ & $\mathbf{\square}$ & $\mathbf{\square}$ & $\mathbf{\square}$ & $\Delta$ & $\Delta$ \\
\hline \multicolumn{12}{|l|}{ Rainy season } \\
\hline TDS $\left(\mathrm{mg} \mathrm{L}^{-1}\right)$ & 1788.6 & 3349.5 & 1206.2 & 1834.8 & 89.4 & 10015.5 & 2600.4 & 2829.8 & 6831 & 5775 & 6204 \\
\hline Classification & $\mathbf{\square}$ & $\Delta$ & $\mathbf{\square}$ & $\mathbf{\square}$ & O & $\star$ & $\boldsymbol{\square}$ & $\square$ & $\Delta$ & $\Delta$ & $\Delta$ \\
\hline
\end{tabular}

Fresh $=(0-1000)$, Slightly saline $=(1000-3000), \Delta$ Moderately saline $=(3000-10000), \star$ Highly saline $=(10000-35000), *$ Briny $=\left(>35000\left(\mathrm{mg} \mathrm{L}^{-1}\right)\right.$.

group. Most of MORCA's groundwater in the dry season fell within the area of non-dominant type B; however, a few samples can be classified as sodium (cation triangle) and bicarbonate and chloride (anion triangle) types. During the rainy season, groundwater can be classified as calcium, magnesium, and sodium cationic types, and as bicarbonate and chloride anionic types (Fig. 2). Similar results were recorded by CONAGUA (2009a y b), which noted that groundwater from the MORCA belongs to the sodium, calcium, and bicarbonate types $\left(\mathrm{Na}-\mathrm{Ca}-\mathrm{HCO}_{3}\right)$.

A dominance of $\mathrm{Na}$ was found in the EH-2, EB-1, EE-1, El-1, RT-1, and $\mathrm{T}-1$ wells, attributable to the occurrence of salt domes or lenses in the region (Peinado-Guevara et al., 2011), as well as the coastal condition of the study area, with a possible saline intrusion from the shore.
In fact, Mtoni et al. (2012) indicated that water $\mathrm{Cl}^{-}$and $\mathrm{Na}^{+}-\mathrm{Cl}^{-}$chemical types are due to a saline intrusion process caused by stronger interaction between fresh water and seawater in many coastal aquifers, such as MORCA. Since chloride is a dominant anion in seawater and bicarbonate in groundwater, they can be used as end-members of these two water types and can indicate salt-water intrusion (Jamshidzadeh \& Mirbagheri, 2011). Figure 3 shows the $\mathrm{Cl}^{-}$versus $\mathrm{HCO}_{3}^{-}$plots for both climatic seasons. A line with a slope of 2.8 was drawn on the plots to represent the threshold for this process (Raghunath, 1990). For both seasons, $\mathrm{Cl}^{-}$concentration in samples $\mathrm{El}-1$ and $\mathrm{T}-1$ were markedly more than 2.8 times higher than $\mathrm{HCO}_{3}{ }^{-}$concentration, probably due to $\mathrm{Cl}^{-}$external sources. The sites where these samples were collected are the farthest wells from the seacoast and no evidence of salt-water intrusion

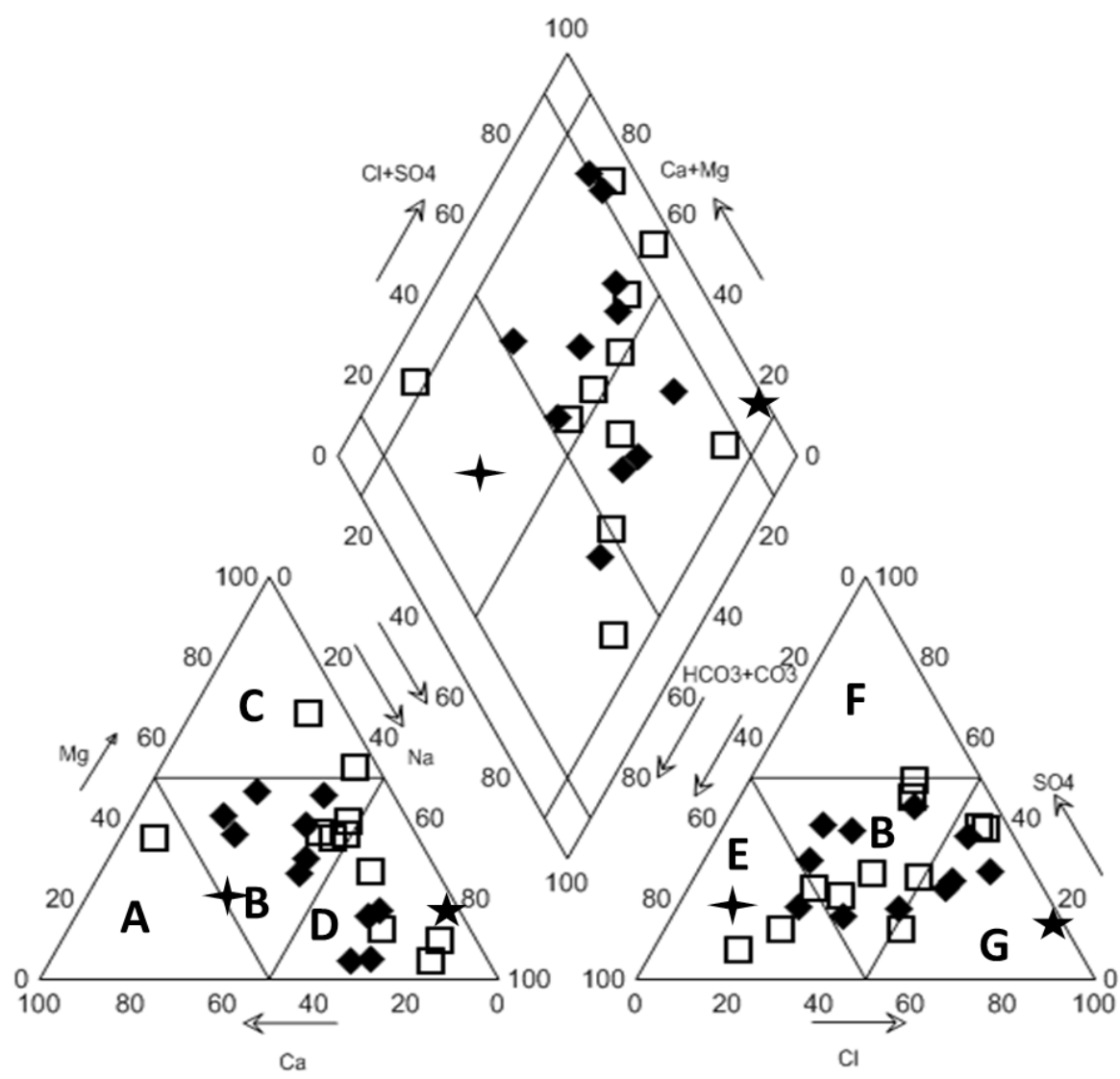

Figure 2. Piper-Hill-Langelier diagram for groundwater samples from the Mocorito River coastal aquife (Sinaloa Mexico) taken in dry ( $\diamond)$ and rainy season ( $\square$ ). A $=$ Calcium Type, $\mathrm{B}=$ no dominant type, $\mathrm{C}=$ Magnesium type, $\mathrm{D}=$ Sodium and potassium type, $\mathrm{E}=$ Bicarbonate type, $\mathrm{F}=$ Sulfate type and $\mathrm{G}=\mathrm{Chloride}$ type. Typical seawater ( $\star$ ) and groundwater ( ). Data were also plotted as references (Millero \& Sohn, 1992). 


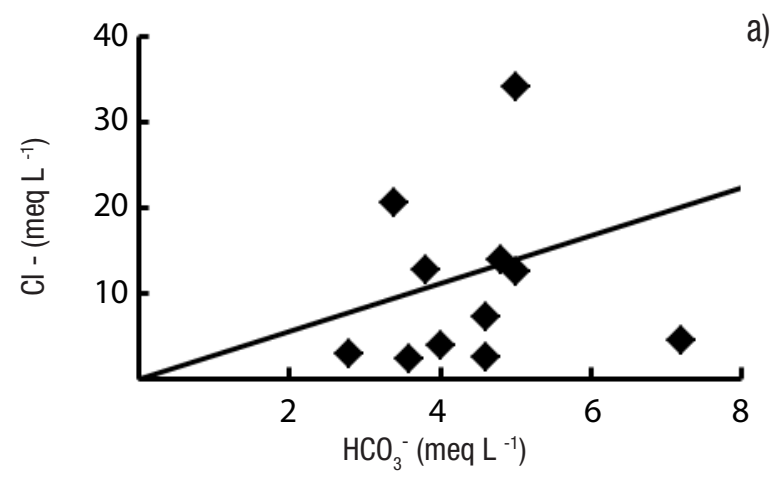

a)

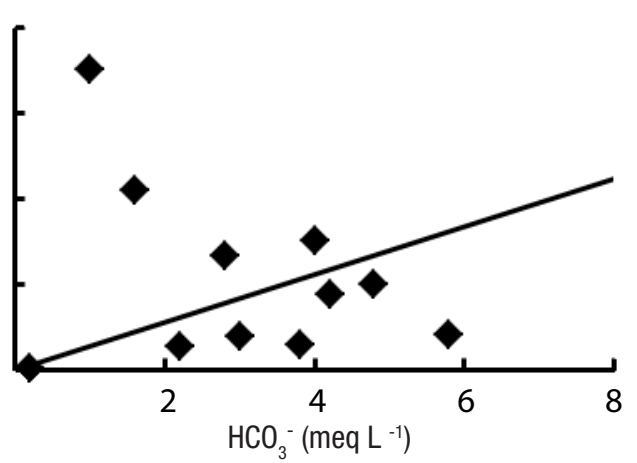

b)

Figures 3a-b. Chlorine versus bicarbonate content in groundwater samples from the Mocorito River coastal aquifer (Sinaloa, Mexico). a) Dry season. b) Rainy season.

was observed in the coastal wells. According to Peinado-Guevara et al. (2011), low-quality water in terms of its salt content was observed in the Sinaloa River coastal aquifer (SIRCA), sufficiently away from the coastline due to occurrence of Pleistocene saline lenses.

We used a Gibbs diagram (1970) in order to understand the geochemical processes (precipitation, rock-interaction, and evaporation dominance) that affect the chemical composition (source of dissolved chemicals) of the MORCA's groundwater. According to this diagram (Fig. 4), the chemical composition of MORCA's groundwater is controlled by processes of evaporation and weathering in both climatic seasons. Similar results have been observed in different studies (Drago \& Quiros, 1996; Subba-Rao, 2006; Peinado-Guevara et al., 2011; Murkute, 2014; Krishna-Kumar et al., 2014), that state that the prevalence of evaporation processes is related to the climate conditions of the region. in semi-dry regions, such as the one where MORCA is located, these climate conditions increase the evaporation rate, raising $\mathrm{Na}^{+}, \mathrm{Cl}^{-}$and TDS contents and, therefore, salinity, such as the waters we studied herein. Likewise, these authors indicate that the dominance of a weathering process is due to water percolating into the subsoil, as well as the lack of good drainage conditions and long residence time of the groundwater that increase rock-water interaction, releasing different ions into the water. Moulla et al. (2013) studied the hydro-geochemistry of the Wadi Nador alluvial aquifer in the Western Algiers Coastal Area. They plotted the $\mathrm{Na}^{+} /$ $\mathrm{Cl}$ ratio vs $\mathrm{Cl}^{-}$concentration and observed two trends; one was related to matrix dissolution, where the ratio variability seems to be independent of chlorinity, and the other, where the ratio increased with chlorine, suggesting marine intrusion. Data from our study were also plotted (Fig. 5) and a matrix dissolution trend was observed, with $\mathrm{Na}^{+} / \mathrm{Cl}^{-}$ratio independent of $\mathrm{Cl}^{-}$concentration.
Water quality for human consumption. Groundwater chemistry has been used as a tool to evaluate water quality for human consumption and agriculture suitability (Subba-Rao, 2006; Vasanthavigar et al., 2010; Krishna-Kumar et al., 2014). For human consumption, two water quality indices were used in this study: (1) WQI proposed by KishnaKumar et al. (2014) and, (2) PHASECH, developed by Peinado-Guevara et al. (2011). Both indices take into account the standard values of several key parameters of groundwater chemistry established by the WHO (2006).

To calculate the WQI, weights (from 1 to 5) were assigned according to the relative importance of each physicochemical parameter in water quality as suggested by Vasanthavigar et al. (2010) and KrishnaKumar et al. (2014): TDS = 5; $\mathrm{pH}, \mathrm{EC}$, and $\mathrm{SO}_{4}{ }^{2-}=4 ; \mathrm{HCO}_{3}{ }^{-}$and $\mathrm{Cl}^{-}=3$; $\mathrm{Ca}^{2+}$ and $\mathrm{Na}^{+}=2 ; \mathrm{Mg}^{2+}=1$. The relative weights were calculated with the following equation:

$$
\mathrm{W}_{\mathrm{i}}=\mathrm{w}_{\mathrm{i}} / \sum_{\mathrm{i}=1}^{\mathrm{n}} \mathrm{w}_{\mathrm{i}}
$$

where $\mathrm{W}_{i}$ is the relative weight and $\mathrm{w}_{i}$ is the weight of each parameter. The quality rating of each parameter $\left(q_{i}\right)$ was calculated by dividing its concentration in a groundwater sample $\left(C_{\text {) }}\right.$ ) by its respective standard value $(\mathrm{S})$ and multiplying by 100 :

$$
\mathrm{q}_{i}=\left(\mathrm{C}_{i} / \mathrm{S}_{i}\right) \times 100
$$

After that, the quality sub-index $\left(\mathrm{SI}_{j}\right)$ was computed for each th parameter:

$$
\mathrm{SL}_{i}=\mathrm{W}_{i} \times \mathrm{q}_{i}
$$

Finally, WQI is determined for each groundwater sample:

$$
\mathrm{WQI}=\Sigma \mathrm{SL}_{i}
$$

Table 3. Mocorito River coastal aquifer groundwater classification based on total hardness (TH). (Classification suggested by Sawyer and McCarty, 1967).

\begin{tabular}{llccccc}
\hline & & \multicolumn{2}{c}{ Number of Samples } & & \multicolumn{2}{c}{ Percentage of samples (\%) } \\
\cline { 3 - 4 } \cline { 6 - 7 } TH $(\mathrm{mg} / \mathrm{L})$ & Water type & Dry & Rainy & & Dry & Reason \\
\hline$<75$ & Soft & - & 1 & & - & 9 \\
$75-150$ & Moderately hard & - & 1 & & - & 9 \\
$150-300$ & Hard & 4 & 2 & & 36 & 18 \\
$>300$ & Very hard & 7 & 7 & & 64 & 64 \\
\hline
\end{tabular}


Water quality classification ranges and types of water based on WQI values suggested by Vasanthavigar et al. (2010) and Krishna-Kumar et al. (2014) are shown in Table 4. According to this classification, most of the MORCA's groundwater is of poor quality, with samples from both climatic seasons falling in the range of poor quality to water unsuitable for drinking purposes; except for samples EB-1 and EE-1 in the rainy season, which were classified as good and excellent water, respectively (Table 5). Onwuka et al. (2013) attributed the contamination of groundwater during the dry season to ion leaching and lower groundwater flow; in the rainy season, water table on the aquifers become shallower, allowing infiltration and percolation of surficial runoff loaded with municipal and agricultural wastewater, which can alter the quality of the receiving water body.

Moreover, the PHASECH index suggested by Peinado-Guevara et al. (2010) considers only five parameters ( $\mathrm{pH}, \mathrm{TH}, \mathrm{Na}^{+}, \mathrm{Cl}^{-}$and TDS), assigning a value of 1 to those parameters that fulfill the World Health Organization quality guideline. The higher the PHASECH value, the better the water quality in terms of the evaluated parameters. The PHASECH values obtained after comparing the values of each parameter measured against the WHO guideline are shown in Table 6. Like the WQI, in terms of the PHASECH index, over $50 \%$ of MORCA groundwater samples can be classified as low to intermediate quality water; while only a few samples had high quality (fulfilled with more than 4 parameters).

According to Paez-0suna et al. (2007), there are 169,232 inhabitants in the study area, with only 40,945 living in Angostura county, where most of the water samples for this study were collected (Instituto Nacional de Estadística y Geografía, 2010). Some of the sampled wells were located inside private houses, where, because of hurricanes and droughts, their owners, as well as the Angostura County Union for Potable Water and Sewage Pipeline System (JUMAPAANG), use groundwater to supply the entire community and cover almost all of human needs for domestic and drinking consumption. Given this use of groundwater, assessing water quality is very important.

For drinking water, several researches have studied groundwater quality (Vasanthavigar, 2010; Nagarajan, 2010; Murkute, 2014; Varol \& Davraz, 2015). In their investigation of water quality in the Tefenni aquifer plain, Turkey, Varol and Davraz (2015) employed WQI and multivariate analysis and showed that close to $90 \%$ of the 52 sampled wells had excellent quality, suitable for human drinking water in both climatic seasons (dry and wet). These authors concluded that the groundwater chemistry of the Tefenni aquifer is affected by two factors: 1 ) water-rock interaction; and 2) agricultural activities in the area. On the other hand, in Mexico, Peinado-Guevara et al. (2011) studied the quality and suitability of SIRCA water for agricultural and domestic use found that the sites with better quality, in terms of the PHASECH index, were located close to the banks of the Sinaloa River, but tended to decrease in quality the closer to the coastline they were. They explained this behavior due to the presence of evaporitic bodies and to the potential effect of the saline intrusion from the seawater. Our study was carried out in the more coastal portion of the MORCA, where the effects of saline intrusion or intensive agriculture can be the main factors affecting water quality.

Water quality for irrigation uses. The assessment of groundwater quality for irrigation purposes was based on the estimation of two secondary parameters: sodium absorption ratio (SAR) and soluble sodium percentage $\left(\% \mathrm{Na}^{+}\right)$, as well as $\mathrm{EC}$ values, which are related to the amount of soluble salts in irrigation water. According to Khodapanah et al. (2009) and Onwuka et al. (2013), reduction in water uptake by plant a)

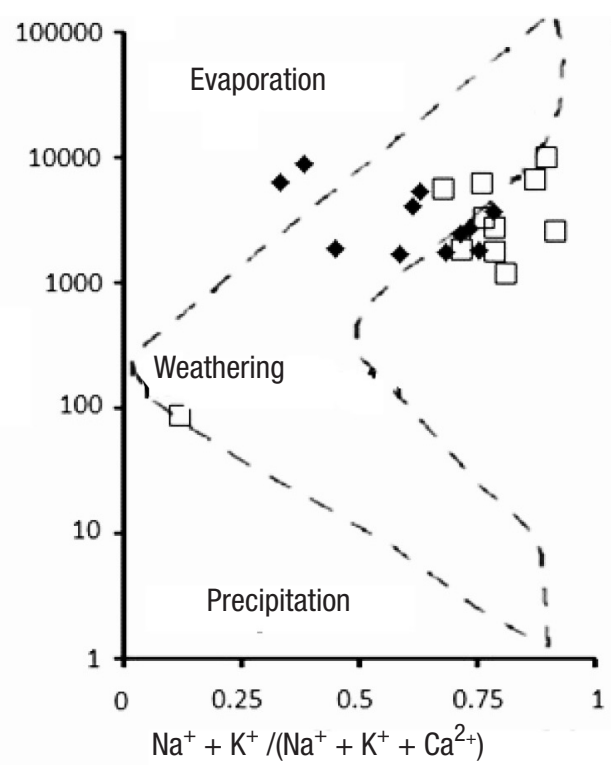

b)

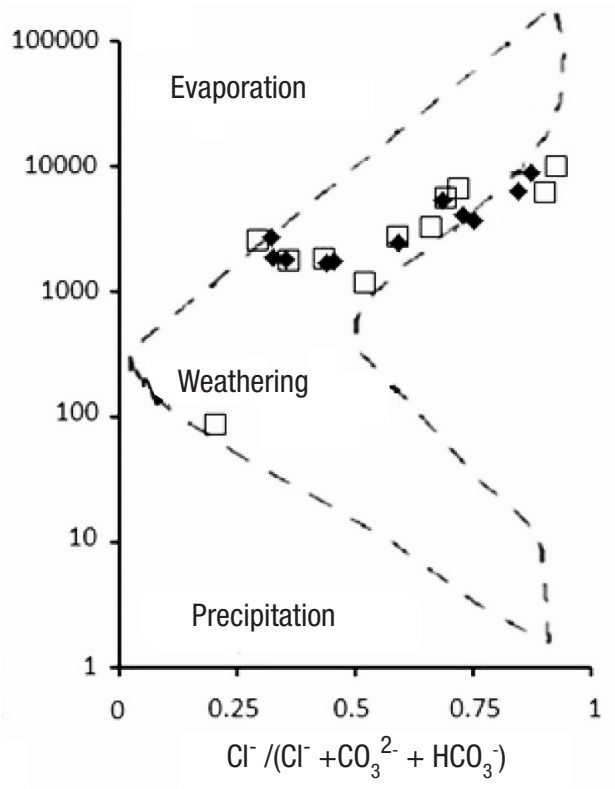

Figures 4a-b. Mechanism affecting the chemical composition of the groundwater samples from the Mocorito River coastal aquifer (Sinaloa, Mexico) in Dry season $(\triangleleft)$ and Rainy season $(\square)$. TDS vs a) cations and b) anions contents (Classification suggested by Gibbs, 1970).

Table 4. Classification of water type suggested by Vasanthavigar et al. (2010).

\begin{tabular}{ll}
\hline Range & Water type \\
\hline$<50$ & Excellent water \\
$50-100$ & Good water \\
$100-200$ & Poor water \\
$200-300$ & Very poor water \\
$>300$ & Water unsuitable for drinking purposes \\
\hline
\end{tabular}




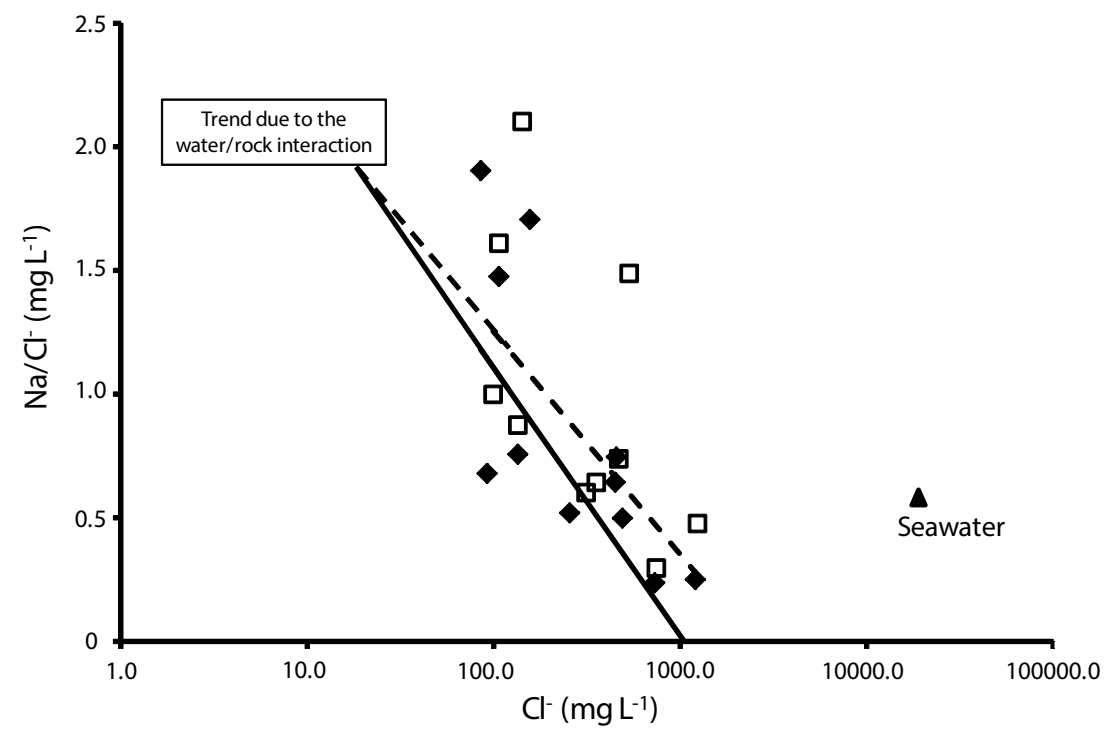

Figure 5. $\mathrm{Na}+/ \mathrm{Cl}-v s \mathrm{Cl}$ - content plots for dry $(\diamond)$ and rainy season $(\square)$ in samples from the Mocorito River coastal aquifer (Sinaloa, Mexico). Seawater data were taken from Millero \& Sohn (1992).

roots may be due to an increase in the osmotic pressure of the soil, which is due to an excess of dissolved solids in the water.

Sodium Absorption Ratio (SAR), \%Na and EC values for MORCA's groundwater samples are shown in Table 1. SAR oscillated between 1.3 and 7.4, with an average of 4.0 for the dry season and from 0.1 to 18.4 , with an average of 5.7 in the rainy season. Similar results were recorded by Vasanthavigar et al. (2010), who indicated that groundwater with SAR $>2$ is unsuitable for irrigation. A higher average of $\% \mathrm{Na}^{+}$was found in the rainy season $(50.3 \%)$ than in the dry season $(45.2 \%)$. The variation in $\% \mathrm{Na}^{+}$between both periods may be due to the residence time of water in the aquifer and the dissolution of minerals from the lithological composition.

Richards (1954) and Wilcox (1948) diagrams were applied to assess water quality for irrigation (Fig. 6 and 7, respectively). Richards (1954) plots the EC values on the " $X$ " axis, which are classified based on salinity (alkali) hazards as follows: low (C1), medium (C2), high (C3), and very high (C4); the SAR values are placed on the "Y" axis and are classified as low (S1), medium (S2), high (S3), and very high sodium hazards (S4). On the other hand, the Wilcox diagram is obtained by plotting the EC values on the " $X$ " axis and \% $\mathrm{Na}^{+}$values on the "Y" axis. This diagram classified water from unsuitable to excellent for irrigation.

In general, groundwater samples from MORCA have combinations of high (C3) to very high salinity risk (C4) and a low (S1) to medium sodium risk (S2) for both climatic seasons; except for two samples from the rainy season that are classified as C3 - S3 and C4 - S4 (Fig. 6). This means that most MORCA's water cannot be used for irrigation in agricultural soils with restricted drainage. For agriculture to be profitable in this region, the soil must have a coarse texture or be organic, with high permeability to allow leachate of irrigation water, with crops and plants appropriately selected for high salinity tolerance (Richards 1954; Wilcox 1955; Ackah et al. 2011).

Table 5. Water quality index (WQI) classification for individual water samples from the Mocorito River coastal aquifer (Sinaloa, Mexico).

\begin{tabular}{ccccc}
\hline \multirow{2}{*}{ ID } & \multicolumn{2}{c}{ Dry season } & \multicolumn{2}{c}{ Rainy season } \\
\cline { 2 - 5 } \cline { 4 - 5 } & WQI & Water type & 116 & Water type \\
\hline EH-1 & 121 & Poor water & 207 & Poor water \\
EH-2 & 251 & Very poor water & 82 & Very poor water \\
EB-1 & 231 & Very poor water & 118 & Good water \\
PI-1 & 110 & Poor water & 18 & Poor water \\
EE-1 & 121 & Poor water & 600 & Water unsuitable for drinking purpose \\
El-1 & 540 & Water unsuitable for drinking purpose & 154 & Poor water \\
EM-1 & 170 & Poor water & 173 & Poor water \\
IA-1 & 151 & Poor water & 421 & Water unsuitable for drinking purpose \\
RB-1 & 115 & Poor water & 358 & Water unsuitable for drinking purpose \\
RT-1 & 331 & Water unsuitable for drinking purpose & 379 & Water unsuitable for drinking purpose \\
T-1 & 393 & Water unsuitable for drinking purpose & &
\end{tabular}




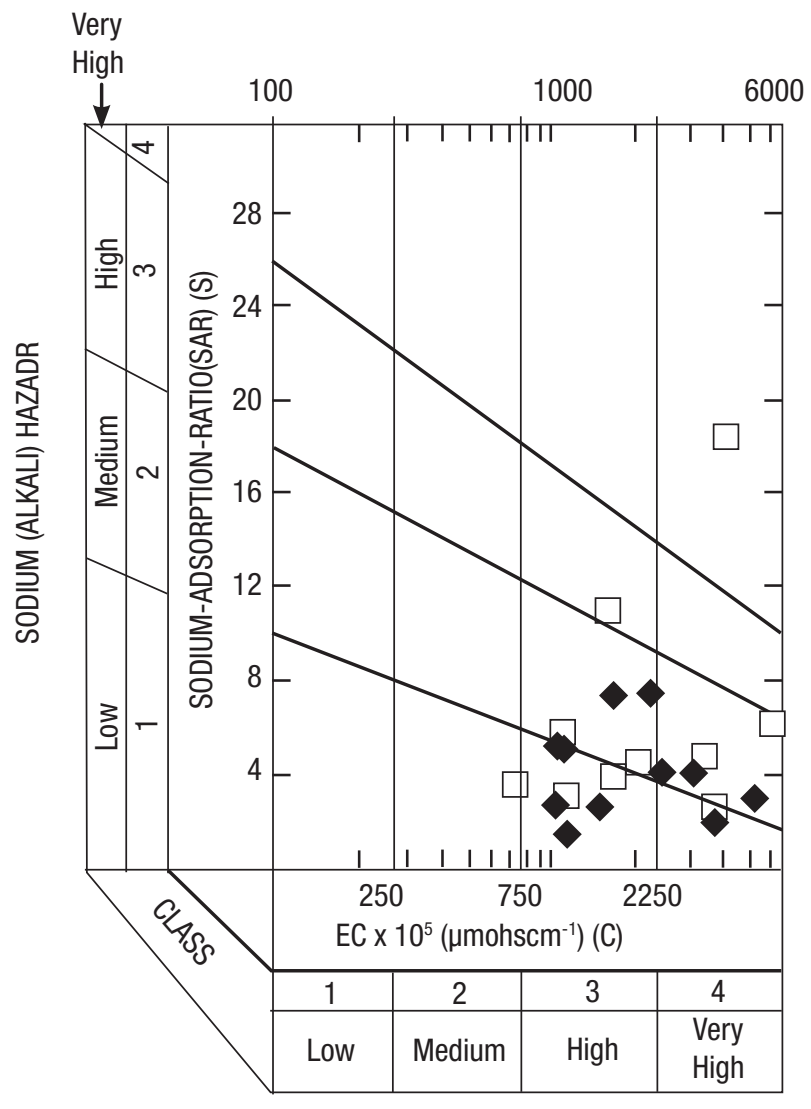

SALINITY HAZARD

Figure 6. US salinity diagram for classification of the groundwater samples from the Mocorito River coastal aquifer (Sinaloa, Mexico) $(\checkmark=$ Dry season; $\square=$ Rainy season).

To confirm the above, a Wilcox diagram (Fig. 7) revealed that only $5 \%$ of the groundwater samples (for both seasons) fell in the excellent to good classification for irrigation, $23 \%$ were classified as good to permissible for irrigation, $27 \%$ were permissible to doubtful water, and the remaining $45 \%$ were classified as doubtful to unsuitable for irrigation.

Paez-0suna et al. (2007) reported that 378,028 ha of agricultural fields lie on the MORCA, a part of the Santa Maria La Reforma Coastal Lagoon sub-basin. About 193,481 ha are used for agricultural irrigation; seasonal agriculture occurs on the remaining 184,547 ha. The extraction of groundwater from the MORCA becomes necessary during severe droughts.

Peinado-Guevara et al. (2011) studied the Sinaloa River aquifer, which is adjacent to the northern portion of MORCA, and observed that almost 35\% of their groundwater samples fell inside the C3 (high salinity hazard) - S1 (low sodium hazard) zone in the US Salinity diagram, suggesting that they are suitable for irrigation. In addition, these authors observed that $52 \%$ of the evaluated water samples were classified as unsuitable for irrigation according to the Wilcox diagram (EC > $3000 \mu \mathrm{S}$ $\left.\mathrm{cm}^{-1}\right)$. Water with low SAR but high EC can be used for irrigation only where fields have efficient drainage.
Nagarajan et al. (2010) state that the concentration of sodium in irrigation water is very important, because a high $\mathrm{Na}^{+}$concentration has the ability to increase the exchange of this ion with the soil and affect its permeability. These authors also indicate that a high combination of $\mathrm{Na}^{+}$and $\mathrm{CO}_{3}{ }^{2-}$ in the water leads to the formation of alkaline soils, while a high combination of $\mathrm{Na}^{+}$and $\mathrm{Cl}^{-}$leads to the formation of saline soils. These two types of soils prevent normal plant growth.

They conclude that MORCA's groundwater has a neutral-alkaline $\mathrm{pH}$ in both dry and rainy seasons, with an average temperature of 26.6 and $28.3^{\circ} \mathrm{C}$, respectively. Most of the MORCA's groundwater can be classified as light to highly saline and moderately to very hard. Ionic concentrations follow the sequence $\mathrm{Cl}^{-}>\mathrm{Na}^{+}>\mathrm{Mg}^{2+}>\mathrm{Ca}^{2+}>\mathrm{SO}_{4}{ }^{2-}>$ $\mathrm{HCO}_{3}{ }^{-}>\mathrm{CO}_{3}{ }^{2-}$ and $\mathrm{Na}^{+}>\mathrm{Cl}^{-}>\mathrm{Mg}^{2+}>\mathrm{SO}_{4}{ }^{2-}>\mathrm{HCO}_{3}{ }^{-}>\mathrm{Ca}^{2+}>\mathrm{CO}_{3}{ }^{2-}$ for dry and rainy seasons, respectively. The Piper diagram revealed hydrochemical facies such as sodium, bicarbonate, and chloride during the dry season; during the rainy season, the facies were calcium, magnesium, sodium, bicarbonate, and chloride types. Furthermore, the Gibbs diagram indicated that the chemistry of MORCA's groundwater is determined by water evaporation and rock-weathering processes.

In terms of water quality, more than $50 \%$ of the groundwater samples were unsuitable for human consumption during both climatic periods; however, two samples had good to excellent quality for consumption. Most of MORCA's groundwater cannot be used for irrigation, since, according to the Richards (1954) diagram samples from most of the sites were classified as C3-S1, C3-S2, C4-S1, and C4-S2. In addition, the Wilcox diagram showed that almost $45 \%$ of the groundwater samples are not suitable for irrigation use.

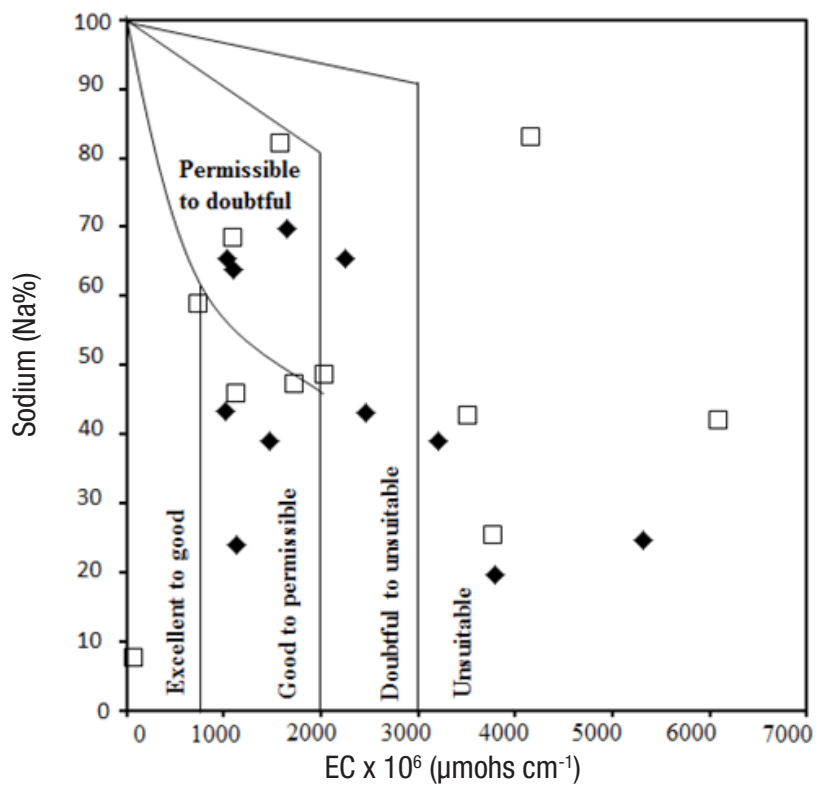

Figure 7. Wilcox diagram for classification of the groundwater samples from the Mocorito River coastal aquifer (Sinaloa, México) for irrigation uses $(>$ Dry season; $\square$ = Rainy season). 
Table 6. Mocorito River coastal aquifer (Sinaloa, Mexico) water quality index (PHASECH) classification.

\begin{tabular}{|c|c|c|c|c|c|c|c|c|c|c|c|c|}
\hline \multirow{2}{*}{ ID } & \multicolumn{2}{|c|}{$\mathrm{pH}$} & \multicolumn{2}{|c|}{$\mathrm{TH}\left(\mathrm{mg} \mathrm{L}^{-1}\right)$} & \multicolumn{2}{|c|}{$\mathrm{Na}^{+}\left(\mathrm{mg} \mathrm{L}^{-1}\right)$} & \multicolumn{2}{|c|}{$\mathrm{Cl}^{-}\left(\mathrm{mg} \mathrm{L}^{-1}\right)$} & \multicolumn{2}{|c|}{ TDS $\left(\mathrm{mg} \mathrm{L}^{-1}\right)$} & \multicolumn{2}{|c|}{ PHASECH* } \\
\hline & Dry & Rainy & Dry & Rainy & Dry & Rainy & Dry & Rainy & Dry & Rainy & Dry & Rainy \\
\hline EH-1 & $\sqrt{ }$ & $\sqrt{ }$ & $\sqrt{ }$ & $\sqrt{ }$ & $\sqrt{ }$ & $\sqrt{ }$ & $\sqrt{ }$ & $\sqrt{ }$ & $x$ & $x$ & 4 & 4 \\
\hline EH-2 & $\sqrt{ }$ & $\sqrt{ }$ & $x$ & $x$ & $x$ & $x$ & $x$ & $x$ & $x$ & $\times$ & 1 & 1 \\
\hline EB-1 & $\sqrt{ }$ & $\sqrt{ }$ & $\sqrt{ }$ & $\sqrt{ }$ & $x$ & $\sqrt{ }$ & $x$ & $\sqrt{ }$ & $x$ & $x$ & 2 & 4 \\
\hline $\mathrm{Pl}-1$ & $\sqrt{ }$ & $\sqrt{ }$ & $\sqrt{ }$ & $\sqrt{ }$ & $\sqrt{ }$ & $\sqrt{ }$ & $\sqrt{ }$ & $\sqrt{ }$ & $x$ & $x$ & 4 & 4 \\
\hline $\mathrm{EE}-1$ & $\sqrt{ }$ & $\sqrt{ }$ & $\sqrt{ }$ & $\sqrt{ }$ & $\sqrt{ }$ & $\sqrt{ }$ & $\sqrt{ }$ & $\sqrt{ }$ & $x$ & $\sqrt{ }$ & 4 & 5 \\
\hline El-1 & $\sqrt{ }$ & $\sqrt{ }$ & $x$ & $x$ & $x$ & $x$ & $\times$ & $x$ & $x$ & $\times$ & 1 & 1 \\
\hline EM-1 & $\sqrt{ }$ & $\sqrt{ }$ & $\sqrt{ }$ & $\sqrt{ }$ & $x$ & $x$ & $\sqrt{ }$ & $\sqrt{ }$ & $x$ & $x$ & 3 & 3 \\
\hline $\mid A-1$ & $\sqrt{ }$ & $\sqrt{ }$ & $\sqrt{ }$ & $\sqrt{ }$ & $\sqrt{ }$ & $\sqrt{ }$ & $\times$ & $x$ & $x$ & $\times$ & 3 & 3 \\
\hline RB-1 & $\sqrt{ }$ & $\sqrt{ }$ & $\sqrt{ }$ & $\sqrt{ }$ & $\sqrt{ }$ & $\times$ & $\sqrt{ }$ & $x$ & $x$ & $\times$ & 4 & 2 \\
\hline RT-1 & $\sqrt{ }$ & $\sqrt{ }$ & $x$ & $x$ & $x$ & $x$ & $x$ & $x$ & $x$ & $\times$ & 1 & 1 \\
\hline $\mathrm{T}-1$ & $\sqrt{ }$ & $\sqrt{ }$ & $\times$ & $\times$ & $\sqrt{ }$ & $\sqrt{ }$ & $\times$ & $\times$ & $\times$ & $\times$ & 2 & 2 \\
\hline
\end{tabular}

$\sqrt{ }$ Under the standard; $\times$ Over the standard; *Peinado-Guevara et al. (2011).

\section{ACKNOWLEDGEMENTS}

This research was funded by the Programa de Apoyo a Proyectos de Investigación e Innovación Tecnológica from the Universidad Nacional Autónoma de México, PAPIIT IN107813, and partially funded by the Programa de Mejoramiento del Profesorado de la Secretaría de Educación Pública, Red Temática de Colaboración Académica, "Contaminación acuática: Niveles y efectos." J. Rivera-Hernández had a Ph. D. fellowship from CONACYT. L. Pelling-Salazar and A. Trejo-Alduenda had Sc. Ms. fellowships from CONACYT. The authors thank Ariel Campo Quintana from the Comisión Nacional del Agua (CONAGUA)-Culiacán for his analytical work and Francisco Montes from CONAGUA-Guamúchil, Nuria Alonso, and Hernán Quiroga for their support in collecting samples.

\section{REFERENCES}

Anonymous, 1978. Atlas geológico y evaluación geológica minera del Estado de Sinaloa. Rodríguez R., Cordoba D. (Eds). Instituto de Geología. Univ. Nal. Autón. México. Hojas I "Mocorito"; II "Culiacán"; III "Tamazula” y IV “La Peña”, México.

Ackah, M., 0. Agymang, A. K. Anim, J. Osel, N. 0. Bentll, L. Kpattah, E. T. GyaMFI \& J. E. K. HANSON. 2011. Assessment of groundwater quality for drinking and irrigation: the case study of Teiman-Oyarifa Community, Ga East Municipality, Ghana. Proceedings of the Internacional Academy of Ecology and Environmental Science 1(3-4): 186-194.

BRINDHA, K. \& L. Elango. 2011. Hydrochemical characteristics of groundwater for domestic and irrigation purpose in Madhuranthakam, Tamil Nadu, India. Earth Sciences Research Journal 15(2): 101-108.

Chol, B. Y., S. T. Yun, S. Y. Yu, P. K. Lee, S. S. Park, G. T. Chae \& B. Mayer. 2005. Hydrochemistry of urban groundwater in Seoul, South Korea: effect of landuse and pollutant recharge. Environmental Geology 48(8): 979-990.

CONAGUA (Comisión Nacional del Agua). 2009a. Acuerdo por el que se da a conocer la ubicación geográfica de 371 acuíferos del territorio nacional, se actualiza la disponibilidad media anual de agua subterránea de 282 acuíferos, y se modifica, para su mejor precisión, la descripción geográfica de 202 acuíferos. (Diario Oficial de la Federación, 28 de agosto de 2009, Gobierno Federal de los Estados Unidos Mexicanos, Segundo, Tercera y Cuarta Secciones. pp. 2-402.

CONAGUA (Comisión Nacional del Agua). 2009b. Actualización de la disponibilidad media anual de agua subterránea y modificación, para su mejor precisión, de la descripción geográfica del acuífero del río Mocorito. Diario Oficial de la Federación, 28 de agosto de 2009, Gobierno Federal de los Estados Unidos Mexicanos. 27 p.

CONAGUA (Comisión Nacional del Agua). 2014. Información histórica, temporada de ciclones 2014. Servicio Meteorologíco Nacional. Disponible en línea en: http://smn.cna.gob.mx/tools/DATA/Climatología/ Pronóstico\%20climático/Temperatura\%20y\%20Lluvia/PREC/2013. pdf (consultado el 7 de febrero de 2017).

Dar, F. A., J. Perrin, Sh. Ahmed, A. C. Narayana \& J. Riotte. 2014. Hydrogeochemical characteristics of karst aquifer from a semi-arid region of southern India and impact of rainfall recharge on groundwater chemistry. Arabian Journal of Geosciences 8 (5): 2739-2750. DOI: $10.1007 / \mathrm{s} 12517-014-1440-9$

Davraz, A. \& A. ÖzDemir. 2013. Groundwater quality assessment and its suitability in Çeltikçi plain (Burdur/Turkey). Environmental Earth Sciences 72 (4): 1167-1190. DOI: 10.1007/s12665-013-3036-1

Drago, E. \& R. Quiros. 1996. The hydrochemistry of the inland waters of Argentina: a review. International Journal of Salt Lake Research 4 (4): 315-325.

García, E. 1964. Modificaciones al sistema de clasificación climática de Koppen. Offset Larios, México. 71 p.

GIBBS, R. J. 1970. Mechanisms controlling world water chemistry. Science 170 (3962): 1088-1090.

HeATH, R. C. 1983. Basic ground-water hydrology. U.S. Geological Survey. Geological Survey Water-supply paper 2220. Reporte técnico. $84 \mathrm{p}$.

INEGI (Instituto Nacional de Estadística, Geografia e Informática). 1995. Estudio Hidrológico del Estado de Sinaloa. Gobierno del Estado de Sinaloa. 40 p. 
JamshidZAdeh, Z. \& S. A. MirBagheri. 2011. Evaluation of groundwater quantity and quality in the Kashan Basin, Central Iran. Desalination 270: 23-30. DOl:10.1016/j.desal.2010.10.067

Khodapanah, I., W. N. A. Sulaiman \& N. Khodapanah. 2009. Groundwater quality assessment for different purposes in Eshtehard District TehranIran. European Journal of Scientific Research 36 (4): 543-553.

Krishna-Kumar, S., A. Logeshrumaran, N. S. Magesh, P. S. Godson \& N. ChanDRASEKAR. 2014. Hydro-geochemistry and application of water quality index (WQI) for groundwater quality assessment, Anna Nagar, part of Chennai City, Tamil Nadu, India. Applied Water Science 5 (4): 335-343. DOI: 10.1007/s13201-014-0196-4.

Milıero, F. J. \& M. L. Sohn. 1992. The Composition of the Major Components of Seawater. In: Millero F. J. (Ed). Chemical Oceanography. CRC Press Inc. United Stated of America. 59-113 p.

Moulla, A. S., A. Guendouz, M. Belaidi, H. Maamar \& S. Ouarezki. 2013. Hydrogeochemical and Isotopic Assessment of Seawater Intrusion into wadi Nador Alluvial Aquifer in the Western Algiers Coastal Area (Tipaza, Algeria). Applied Isotopic Geochemistry Conference (AlG10-10 ${ }^{\text {th }}$ ). Available online at: https://www.researchgate.net/ profile/Adnane_Moulla/publication/268786366_Hydrogeochemical_and_Isotopic_Assessment_of_Seawater_Intrusion_into_ wadi_Nador_Alluvial_Aquifer_in_the_Western_Algiers_Coastal_Area_Tipaza_Algeria/links/5475c9300cf2778985af1145/ Hydrogeochemical-and-Isotopic-Assessment-of-Seawater-Intrusion-into-wadi-Nador-Alluvial-Aquifer-in-the-Western-AlgiersCoastal-Area-Tipaza-Algeria.pdf (downloaded February 20, 2017).

Mtoni, Y., I. MJemah, K. Msindal, M. Van-Camp \& K. Walraevens. 2012. Saltwater intrusión in the quaternary aquifer of the Dar Es Saalam Region, Tanzania. Geologica Belgica 15 (1-2): 16-25.

MuRKutE, Y. A. 2014. Hydrogeochemical characterization and quality assessment of groundwater around Umrer coal mine area Nagpur District, Maharashtra, India. Environmental Earth Sciences 72 (10): 4059-4073. DOI: 10.1007/s12665-014-3295-5.

Nagarajan, R., N. Rajmohan, U. Mahendran \& S. Sentamilkumar. 2010. Evaluation of groundwater quality and its suitability for drinking and agriculture use in Thanjavur City, Tamil Nadu, India. Environmental Monitoring and Assesment 171 (1-4): 289-308. D0l: 10.1007/ s10661-009-1279-9.

Onwuka, 0. S., 0. V. Omonona \& 0. C. AniKa. 2013. Hydrochemical characteristics and quality assessment of regolith aquifers in Enugu metropolis, southeastern Nigeria. Environmental Earth Sciences 70 (3): 1135-1141. D0I: 10.1007/s12665-012-2200-3.

Páez-Osuna, F., G. Ramírez-Reséndiz, A. C. Ruiz-Fernández \& M. F. Soto-JiméNEZ. 2007. La Contaminación por Nitrógeno y Fósforo en Sinaloa: Flujos, Fuentes, Efectos y Opciones de manejo. In: Páez-Osuna F. (Ed.). La Serie Las Lagunas Costeras de Sinaloa. UNAM, El Colegio de Sinaloa, México, D.F. 304 p.
Peinado-Guevara, H. J., C. R. Green-Ruiz, J. Herrera-Barrientos, 0. A. Escolero-Fuentes, 0. Delgado-Rodríguez, S. I. Belmonte-Jiménez \& M. A. LadRón-de Guevara. 2011. Calidad y aptitud de uso agrícola y doméstico del agua del acuífero del río Sinaloa, porción costera. Hidrobiológica 21 (1): 63-76.

PIPER, A. M. A. 1953. Graphic procedure in the geochemical interpretation of water analysis. Groundwater Note 12. United State Geological Survey. $914-928 \mathrm{p}$.

Raghunath, H. M. 1990. Groundwater.Wiley Eastern Limited. New Delhi, p. 563.

RICHARDS, L. A. (1954). Diagnosis and improvement of saline and alkali soils. USDA Handbook. No. 60. US Govt. Press, Washington, DC, 160.

Sánchez-PÉrez, J.M. \& M. Trémolières. 2003. Change in groundwater chemistry as a consequence of suppression of floods: the case of the Rhine floodplain. Journal of Hydrology 270 (1-2): 89-104. DOI: 10.1016/S0022-1694(02)00293-7.

Sawyer, C. N. \& D. L. McCarty. 1967. Chemistry of sanitary engineers. New York: McGraw-Hill. 518 p.

SARH (Secretaria de Agricultura y Recursos Hidráulicos). 1974. Manual para análisis de suelos y aguas. Centro de capacitación en irrigación y drenaje Benito Juárez, El Carrizo, Sinaloa, México. 241 p.

Secretaria de Salud. 2000. Modificación a la Norma Oficial Mexicana NOM-127-SSA1-1994, Salud ambiental, agua para uso y consumo humano, límites permisibles de calidad y tratamientos a que deben someterse el agua para su potabilización. Diario Oficial de la Federación Tomo DLXVI No. 15 Primera Sección 73-79 (publicado 22 de noviembre de 2000).

SuBBA-RAO, N. 2006. Seasonal variation of groundwater quality in a part of Guntur District, Andhra Pradesh, India. Environmental Geology 49: 413-429. DOI: 10.1007/s00254-005-0089-9.

Vasanthavigar, M., K. Srinivasamoorthy, K. Vijayaragavan, R. Rajiv-Ganthi, S. Chidambaram, P. Anadhan, R. Manivannan \& S. Vasudevan. 2010. Application of water quality index for groundwater quality assessment: Thirumanimuttar sub-basin Tamilnadu, India. Environmental Monitoring and Assessment 171 (1): 595-609. D0I: 10.1007/s10661009-1302-1.

VaroL, S. \& A. Davraz. 2015. Evaluation of the groundwater quality with WQI (Water Quality Index) and multivariate analysis: a case study of the Tefenni Plain (Burdur/Turkey). Environmental Earth Science 73 (4): 1725-1744. D0l: 10.1007/s12665-014-3531-z.

WhO (World Health Organization). 2006. Guidelines for drinking-water quality. First addendum to volume 1. 3a. Ed. 515 p

WıLcox, L. V. 1948. The quality of water for irrigation Use. Technical BuIletins 962: 1-40.

WıLcox, L. V. 1955. Classification and use of irrigation waters. United Stated Department of Agriculture, Circular 969. 21 p. 